\title{
The Cause Of Construction Material Wastage In Building Construction Projects: A Study In Wolaita Zone, Southern Ethiopia
}

\author{
Wondimagegn Tadesse Borku ${ }^{1}$, EsubalewTarku Yenialem ${ }^{2}$ \\ ${ }^{1}$ Lecturer, Department of Construction technology and management, WolaitaSodo University, Ethiopia \\ Email id:wondetade@gmail.com \\ ${ }^{2}$ Lecturer, Department of Civil Engineering, Wolaita Sodo University,Ethiopia
}

Email id: esubalewtariku@yahoo.com

*Corresponding Author: Wondimagegn Tadesse Borku

Lecturer, Department of Construction technology and management, WolaitaSodo University, WolaitaSodo, Ethiopia

Email Id: wondetade@gmail.com

\begin{abstract}
Construction materials waste causes serious environmental problems and project cost overruns in many construction projects. Building material waste can be defined as the difference between the value of materials delivered and accepted on site and those properly used as specified and accurately measured in the work, after deducting the cost saving of substituted materials transferred. The methods that used for this thesis were by collecting the data require for this study through preparing questionnaires. Based on the results from the analysis the following conclusions have been derived and summarized in accordance with the objectives of the research. Based on finding researchers determined different factors. Key factors were Lack storage of materials near of construction site, Wrong storage of materials, Poorly schedule to procurement the Materials, Purchased materials that don't comply with specification, Insufficient instructions about storage and Stacking, Over ordering due to mistake in quantity surveys, Overproduction/Production of a quantity, greater than required or earlier than necessary, Inadequate stacking and insufficient storage on site, Damage materials on site, Using excessive quantities of materials more than the required, Wrong handling of materials, Insufficient instructions about handling, Damage during transportation, Manufacturing defects, Ordering of materials that do not fulfill project requirements and Unnecessary inventories in site which lead to waste
\end{abstract}

Key words: Construction materials waste,cost overruns and Damage material

\subsection{Background of the Study}

\section{INTRODUCTION}

Wastage is seen in many ways as individuality of construction projects. This means that many construction works have wastage because it is an issue that cannot be separated from construction work. There have been different definitions of construction materials waste by different authors. For the purpose of this study, building materials wastage can be defined as the difference between the value of materials delivered and accepted on site and those properly used as specified and accurately measured in the work after deducting the cost saving of substituted materials transferred elsewhere in which unnecessary cost and time may be incurred by the materials wastage.[19] The causes of construction materials waste can be measured and evaluated using a large number of construction phase related factors such as design and documentation, materials procurement and management, site management practices and site supervision including environmental conditions.[1] The first set is related to designers and client's requirements; the people who consider the functional requirement of the building. The second set is related to construction team and contractors; people who consider the build ability and maintainability of the building. The third set is related to the site supervisors and the site operatives; people who are directly involved in the art of putting the raw materials together to form the building envelop(Shen and Tam, 2002). Construction materials waste causes serious environmental problems and project cost overruns in many construction projects. Building material waste can be defined as the difference between the value of materials delivered and accepted on 
site and those properly used as specified and accurately measured in the work, after deducting the cost saving of substituted materials transferred.[2]

Therefore construction materials wastage on construction sites contributes to cost overruns. This implies that detailed review, identification of causal factors of construction materials waste, assessment of these factors and any improvement in material wastage management on construction sites will enhance the cost performance of construction projects in sodo town.

\subsection{Statement of the Problem}

Past research into the causes of construction materials waste in construction projects indicate that waste can arise at any stage of the construction process from beginning, right through the design, construction and operation of the built facility. Construction materials waste causes serious environmental problems and project cost overruns in many construction projects. Building material waste can be defined as the difference between the value of materials delivered and accepted on site and those properly used as specified and accurately measured in the work, after deducting the cost saving of substituted materials transferred).[3]

With the increase in construction activities and shortage of suitable landfill sites, lack of material resources and limited of fund, construction waste is becoming a serious problem in wolayita zone and no attention is given to such subject.

\subsection{Objectives of the Study}

The central goal of this research work is to identify and determine the cause"sconstruction material wastage in building construction projects.

\subsection{Definitions and Concepts}

\section{REVIEW OF LITERATURES}

Waste can be classified into unavoidable waste (or natural waste), in which the investment necessary to its reduction is higher than the economy produced, and avoidable waste, when the cost of waste is significantly higher than the cost to prevent it.

The causes of construction materials waste can be measured and evaluated using a large number of construction phase related factors such as design and documentation, materials procurement and management, site management practices and site supervision including environmental conditions.[4] The first set is related to designers and clientes requirements; the people who consider the functional requirement of the building. The second set is related to construction team and contractors; people who consider the build ability and maintainability of the building. The third set is related to the site supervisors and the site operatives; people who are directly involved in the art of putting the raw materials together to form the building envelop(Shen and Tam, 2002)[18]

\subsection{Construction materials waste generated by construction activities}

The way construction activities are carried out during the construction process also impacts on the quantity of waste produced. This waste is usually ,accidental ${ }^{\text {le }}$ and is generated by the following factors:

* Inaccurate or surplus ordering of materials that don "t get used

* Damage through handling errors

* Damage through inadequate storage

* Damage generated by poor co-ordination with other trades

* Rework due to low quality of work

* Inefficient use of materials

* Temporary works materials

Construction material waste has been considered to be a major problem in the construction industry. Material waste in construction is focused on the quantity of waste of materials on site. Material waste in the construction industry has been the subject of several research projects around the world in recent years. Some of them have focused on the environmental damage that results from the generation of materialwaste.[17]Construction materials waste comprises of unwantedmaterials generated during construction, including rejected structures and materials, materials which have been over ordered or are surplus to requirements, and materials which have been used and discarded. [5]

Waste arises from a number of different activities carried out by the contractor during construction and maintenance and mayinclude: 
* Woodfrom formwork and false work,

* material and equipment wrappings,

* unusable or surplus cement/ grouting mixes, damaged/surplus/contaminated construction materials.

Building material waste can be defined as the difference between the value of materials delivered and accepted on site and those properly used as specified and accurately measured in the work, after deducting the cost saving of substituted materials transferred elsewhere, in which unnecessary cost and time may be incurred by materials wastage.[6]

\subsection{Sources and causes of material waste}

Many factors contribute to construction waste generation on site. Waste may occur due to one or a combination of many causes such as:

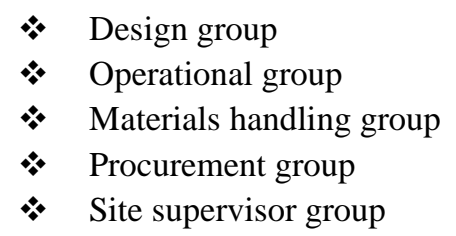

Design:-Wastage which comes from design and documentations are:-

Lack of attention paid to dimensional coordination of products

* Changes made to the design while construction is in progress

* Lack of attention paid to standard sizes available on the market

* Complexity of detailing in the drawings

* Lack of information in the drawings

* Errors in contract documents

* Incomplete contract documents at commencement of project

* Selection of low quality products

\section{Operational;}

* Errors by tradespersons or laborers

- Accidents due to negligence

* Damage to work done caused by subsequent trades

* Use of incorrect material, thus requiring replacement

* Required quantity unclear due to improper planning

* Delays in passing of information to the contractor on types and sizes of products to be used Equipment malfunctioning

\section{Material handling;}

* Inappropriate storage leading to damage or deterioration

* Materials supplied in loose form

* Use of whatever material which are close to working place

* Unfriendly attitudes of project team and laborers

* Damages during transportation

\section{Procurement;}

- Ordering errors (e.g. ordering significantly more or less)

- Lack of possibilities to order small quantities

- Purchased products that do not comply with specification

\section{Overproduction;}

It is related to the production of a quantity greater than required or earlier than necessary. This may cause waste of materials, Man-hours or equipment usage. It usually produces inventories of unfinished products or even their total loss, in The case of materials that can deteriorate. An example of this kind of waste is the overproduction of mortar that cannot be used on time.[7] 


\section{Substitution;}

It is Related to the substitution of a material by a more expensive one (with an unnecessary better performance); the execution of simple tasks by an over-qualified worker; or the use of highly sophisticated equipment where a much simpler one would be enough.[16]

\section{Transportation;}

This is concerned with the internal movement of materials on site. Excessive handling, the use of inadequate equipment or bad Conditions of pathways can cause this kind of waste. It is usually related to poor layout, and the lack of planning of Material flows. Its main consequences are: waste of man hours, waste of energy, waste of space on site, and the Possibility of material waste during transportation.[8]

\subsection{Research Design}

\section{RESEARCH METHODOLOGY}

The design used for this study is that of a survey which relied on a questionnaire surveys to generate data for the analysis. The questions were constructed using the Likert scale. The respondents were asked to rank on a scale of 0-4 factors that cause materials waste on construction sites where $4=$ Very high causes, $3=$ high causes, $2=$ moderate causes, $1=$ low causes, $0=$ not causes at all.

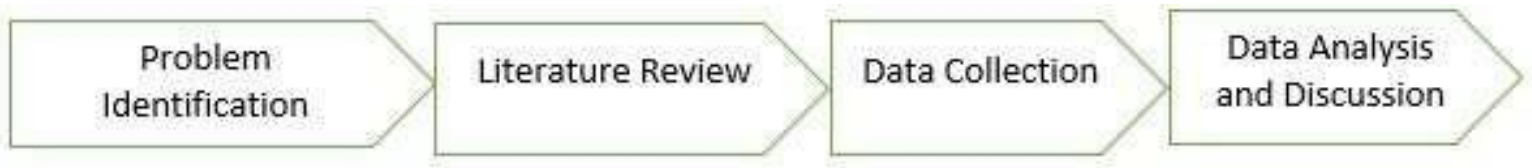

Figure 1: Flow Chart of for research design

The research data was obtained with the aid of a structured questionnaire survey (quantitative method), which was authenticated by conducting qualitative method shortly after the questionnaire survey. The quantitative method was used to collect data from construction stakeholders and contractors to identify factors causing material wastage in building construction projects. Furthermore, exploratory type of study was employed in order to get a research questionnaire/surveys design to gain more perception into the research problem and to deliver solutions. [9]

\subsection{Data collection}

The study depended on both primary and secondary data. Primary data was made up of first-hand data collected by the candidate through the use of questionnaires, interviews and site visits (observation). The secondary sources of data were obtained using relevant books, journals, magazines and research papers.

\subsection{Population of the Study.}

The majority of the survey participants were construction professionals with all-embraced construction knowledge, skill and formal education. Site, contract, and project managers, site supervisors, designers, site engineers and quantity surveyors were the particularly nominated sample to denote the population for the purpose of this study. [10]The buildings under construction were selected from the list of registered buildings in construction using multistage random sampling. From the list of registered buildings, every fifth buildings under construction were chosen using random sampling till the required sample was reached.From the total 25 distributed questionnaires 20 questionnaires were received and the study conducted.

\subsection{Sampling Technique}

To confirm the data obtained from the questionnaires; contractors, site supervisors and government experts were interviewed. These participants were selected for interviews using the suitability sampling method.[11] Participants interviewed had adequate experience in construction, with adequate years of experience and responsibilities in the construction sector. 


\subsection{Instrument for Data Collection}

Data was collected using open-ended and close-ended questionnaires in relation with the research objectives. Qualitative interviews were used to confirm the findings obtained through the quantitative research. Moreover, observations were also used as a technique that helped to get information that is left during formal interview sessions with informants just to grasp information about the unstated things during the interview and informal conversation periods.[12]

\subsection{Techniques of Data Analysis}

Data were analyzed using descriptive analysis. All the statistical analyses and tests were done using application software "Microsoft excel". A Likert scale was used to measure the key indicators for cost inflation construction materials and to determine the range of each respondent"s ranking of 0-4 (4 very high cause), 3 for High cause), 2 for moderate cause), 1 for low cause) and 0 for no cause at all.[13]

Finally, the Relative Important Index (RII) method was adopted for determining the rank for the "key factors Sustainable Construction Materials" by calculating the average of relative importance index of all factors in the group. $R I I=\left(\frac{\sum(W)}{A^{*} N}\right)$

Where: $\mathrm{W}=$ the weight given to each factor by the respondents

A $=$ very high cause $=4$

$\mathrm{N}=$ the total number of respondents.

\subsection{General Information}

\section{RESULTS AND DISCUSSION}

The objective of this study is to identify and determine the cause"s construction material wastage in building construction projects.To accomplish this goals a questionnaire was developed and distributed to be filled by the concerned body in the construction sectors in WolaitaSodo.[14] from the average result shown on above table, the major and dominant causes construction material wastage was Insufficient instructions about handling with the highest value of RII $=0.76$, second dominant was Unnecessary inventories in site which lead to waste with RII $=0.75$, third dominant wasPurchased materials that don't comply with specification with RII value $=0.69$ and minimum causes was damage during transportation with RII value 0.34 [15] As we see from the above table.

Table1: Study Results from the respondents for the Key Factors for the cause"s construction material wastage in wolaitasodo building construction projects 


\begin{tabular}{|c|c|c|c|c|c|c|c|}
\hline Key Factors & $\begin{array}{l}4=\text { Very } \\
\text { high } \\
\text { causes }\end{array}$ & $\begin{array}{l}3= \\
\text { high } \\
\text { causes }\end{array}$ & $\begin{array}{l}2= \\
\text { moderate } \\
\text { causes }\end{array}$ & $\begin{array}{l}1=\text { low } \\
\text { causes }\end{array}$ & $\begin{array}{l}0=\text { not } \\
\text { causes } \\
\text { at all }\end{array}$ & Total & RII \\
\hline $\begin{array}{l}\text { Lack storage of materials near of } \\
\text { construction site }\end{array}$ & 6 & 5 & 6 & 1 & 2 & 20 & 0.65 \\
\hline Wrong storage of materials & 5 & 5 & 6 & 4 & 0 & 20 & 0.60 \\
\hline $\begin{array}{l}\text { Poorly schedule to procurement the } \\
\text { Materials }\end{array}$ & 4 & 3 & 7 & 3 & 3 & 20 & 0.54 \\
\hline $\begin{array}{l}\text { Purchased materials that don't comply with } \\
\text { specification }\end{array}$ & 7 & 4 & 6 & 3 & 0 & 20 & 0.69 \\
\hline $\begin{array}{l}\text { Insufficient instructions about storage and } \\
\text { Stacking }\end{array}$ & 6 & 4 & 6 & 4 & 0 & 20 & 0.64 \\
\hline $\begin{array}{l}\text { Over ordering due to mistake in quantity } \\
\text { surveys }\end{array}$ & 5 & 6 & 5 & 3 & 1 & 20 & 0.65 \\
\hline Overproduction/Production of a quantity & 4 & 7 & 3 & 5 & 1 & 20 & 0.58 \\
\hline $\begin{array}{l}\text { greater than required or earlier than } \\
\text { necessary }\end{array}$ & 3 & 4 & 2 & 7 & 4 & 20 & 0.41 \\
\hline $\begin{array}{l}\text { Inadequate stacking and insufficient } \\
\text { storage on site }\end{array}$ & 5 & 3 & 6 & 5 & 1 & 20 & 0.60 \\
\hline Damage materials on site & 4 & 4 & 4 & 4 & 4 & 20 & 0.51 \\
\hline $\begin{array}{l}\text { Using excessive quantities of materials } \\
\text { more than the required }\end{array}$ & 6 & 6 & 5 & 3 & 0 & 20 & 0.70 \\
\hline Wrong handling of materials & 2 & 8 & 3 & 4 & 3 & 20 & 0.51 \\
\hline Insufficient instructions about handling & 4 & 9 & 7 & 0 & 0 & 20 & 0.76 \\
\hline Damage during transportation & 3 & 3 & 3 & 7 & 4 & 20 & 0.34 \\
\hline Manufacturing defects & 2 & 2 & 8 & 5 & 3 & 20 & 0.46 \\
\hline $\begin{array}{l}\text { Ordering of materials that do not fulfill } \\
\text { project requirements. }\end{array}$ & 3 & 1 & 9 & 4 & 3 & 20 & 0.48 \\
\hline $\begin{array}{l}\text { Unnecessary inventories in site which lead } \\
\text { to waste }\end{array}$ & 6 & 8 & 4 & 1 & 1 & 20 & 0.75 \\
\hline
\end{tabular}




\section{CONCLUSTIONS}

To identify and determine the cause $\mathrm{s}$ construction material wastage in building construction project. To achieve these objectives, the study used questionnaire survey as a research instrument. The information gathered from the survey was analyzed using the percentage method and relative importance index method.

Based on the results from the analysis the following conclusions have been derived and summarized in accordance with the objectives of the research. Based on finding researchers determined different factors. Key factors were Lack storage of materials near of construction site, Wrong storage of materials, Poorly schedule to procurement the Materials, Purchased materials that don't comply with specification, Insufficient instructions about storage and Stacking, Over ordering due to mistake in quantity surveys, Overproduction/Production of a quantity, greater than required or earlier than necessary, Inadequate stacking and insufficient storage on site, Damage materials on site, Using excessive quantities of materials more than the required, Wrong handling of materials, Insufficient instructions about handling, Damage during transportation, Manufacturingdefects, Ordering of materials that do not fulfill project requirements and Unnecessary inventories in site which lead to waste

\section{REFERENCES}

[1] Teo, S.P., Abdelnaser, O. And Abdul, H.K. (2009), Material Wastage.

[2] Formoso, C. T., Soibelman L., Cesare, C. D. and Isatto, E. L., (2002). Material Waste in Building Industry: Main Causes and Prevention. Journal of Construction, Quality assurance techniques,

[3] Dr.A. Paulmakesh, Gizachew Markos Makebo April 2021, "Management of contracts for Durable structures" Innovations, Number 64,Pg 1044-1054

[4] Construction defect (J. Norman Stark, Attorney-At-Law)

[5] Shen and Tam, 2002,material wastage

[6] Dr.A. Paulmakesh, Dec 2021, "Analysis of uncertainty in a construction project" YMER journal, Vol 20,Issue 12, pg.no 324-332.

[7] (David, 1997). (Building defect: umpire.ump.edu.my/1269/1/CD4379PDF)

[8] Consequences of construction defects: (JOSEPH M. JUNFOLA, CPCU, 2013.)

[9] Yimam Mohammed, A. Paulmakesh, Bereket Admasu amd Saliha Shukri, Oct 2021, "Relationship between California Bearing Ratio and Other Geotechnical Properties of Sub grade Soils", ICEPAE 2021, Journal of Physics Conference Series, Vol 2040(1):012024, doi:10.1088/1742-596/2040/1/012029, pg.no 1-13.

[10] (Barry A. Richardson, 2001). Engineering approach system to assess defect

[11] Akintola. (n.d.). Macro-economic leading indicators of construction contract prices, Construction Management \& Economics. Taylor and Francis Journals. .

[12] AstewayYigezu. (2008). Study on the Effects of Unpredictable Price Fluctuation on the Capacity of Construction Contractors.

[13] Atkeson, Andrew and Lee E. Ohanian. (2001), are phillips curves Useful for Forecasting Inflation. Balsubaramanin, P. A. (October 2017,). Classification of Materials.

[14] Dr.A. Paulmakesh, Yimam Mohammed Yimer April 2021, "Implementation of Project Management for Strategy Realisation" Journal of University shanghai for Science and Technology , Volume 23, Issue 10,Pg.No 887-892

[15] Goyals, s. (2017). effecte of inflation on project cost in rajasthan.

[16] Hanna, A. T. (2005). Impact of extended overtime on construction labor productivity. . Journal of construction engineering and management, 734-739.

[17] Yimam Mohammed Yimer, A. Paul Makesh and SalihaShukri Muhammed, Oct 2021, "Prediction of undrained shear strength and correlation in between soil parameters", ICEPAE 2021,Journal of Physics Conference Series, Vol 2040(1):012029, doi:10.1088/1742-6596/2040/1/012024 pg.no 1-8.

[18] MAkulsawatudom, A. a. (2001). Factors affcting the productivity of the construction industry in Thailand:

[19] Mohammed, G. (2013). Assessment of price escalation and adjestement problems on federal road construction projects. 